\title{
Effect of the IGF-I gene polymorphism on growth, body size, carcass and meat quality traits in Coloured Polish Merino sheep
}

\author{
Ewa Grochowska ${ }^{1}$, Bronisław Borys ${ }^{2}$, Piotr Janiszewski ${ }^{3}$, Jan Knapik ${ }^{4}$, and Sławomir Mroczkowski ${ }^{1}$ \\ ${ }^{1}$ Department of Genetics and General Animal Breeding, UTP University of Science and Technology, \\ Bydgoszcz, Poland \\ ${ }^{2}$ National Research Institute of Animal Production, Experimental Station, Kołuda Wielka, Poland \\ ${ }^{3}$ Department of Meat and Fat Technology, Prof. Wacław Dąbrowski Institute of Agricultural and Food \\ Biotechnology, Warsaw, Poland \\ ${ }^{4}$ National Research Institute of Animal Production, Balice, Poland \\ Correspondence to: Ewa Grochowska (grochowska@utp.edu.pl)
}

Received: 22 February 2017 - Revised: 24 April 2017 - Accepted: 5 May 2017 - Published: 14 June 2017

\begin{abstract}
Insulin-like growth factor I, encoded by the $I G F-I$ gene, plays a role in cell growth and differentiation, embryogenesis, metabolism regulation, skeletal growth, and protein synthesis. The aims of this study were to investigate the polymorphism in the $5^{\prime}$ flanking region of the $I G F-I$ gene and evaluate associations between the single-nucleotide polymorphism (SNP) in this gene and growth, body size, carcass and meat quality traits in Coloured Polish Merino sheep. In total 78 live and post mortem traits were investigated. Polymorphism in the IGF-I gene was identified with the use of the polymerase chain reaction restriction fragment length polymorphism (PCR-RFLP) method in 305 Coloured Polish Merino sheep. In association studies, traits of interest were analysed with the use of the MIXED and GENMOD procedures of the SAS statistical package. Two alleles named A and B, and two IGF-I genotypes - AA and AB - were detected. The A allele and the AA genotype were predominant, with the frequencies of 91.6 and $83.3 \%$, respectively. The $I G F-I$ genotype was found to have a highly significant effect on fore shank weight $(P=0.006)$, kidney fat class $(P=0.002)$ and EUROP fat class $(P=0.005)$. Furthermore, the $I G F-I$ genotype significantly affected external fatness of carcass class $(P=0.038)$, drip loss $(P=0.049)$, and subjective assessment of meat colour $(P=0.043)$, and it tended to be associated with longissimus dorsi $(L D)$ muscle width $(P=0.063)$ and flavour $(0.067)$. Concluding, the IGF-I gene could be considered as a candidate gene of selected carcass and meat quality traits in sheep.
\end{abstract}

\section{Introduction}

Insulin-like growth factor I (IGF-I) is a polypeptide hormone that is encoded by the $I G F-I$ gene and is similar in molecular structure to insulin. IGF-I participates in the somatotrophic axis together with growth-hormone-releasing hormone $(\mathrm{GHRH})$, growth hormone $(\mathrm{GH})$, insulin-like growth factor II (IGF-II), and their associated binding proteins (BPs) and receptors (GHRHR, GHR, IGF-IR and IGF-IIR). Moreover, it interacts with insulin-like growth factor I receptors (IGF-IR) in target tissues (Jones and Clemmons, 1995) and with proteins binding IGF in blood (IGF-BP), which can modulate action of this hormone (e.g. Lackey et al., 1999; Schams et al., 1999). IGF-I is also believed to mediate a wide spectrum of biological responses such as cell growth and differentiation, embryogenesis, metabolism regulation, skeletal growth, and protein synthesis (Baxter, 1986; Clemmons et al., 1987; Froesch et al., 1985). For these reasons, the IGF-I gene is considered as a functional candidate for a number of production traits, i.e. growth, carcass and meat quality traits in livestock.

Growth traits are important attributes in sheep breeding, as they, among other factors, affect breeder's profit. Lamb body weight is one of the factors that regulate incomes from meat 
production. Therefore, the improvement of these traits should be one of the most important aims in sheep production. Growth traits, like other quantitative traits, are controlled by several genes, e.g. the IGF-I gene, and environmental factors. However, there have been only a few association analyses of the $I G F-I$ gene polymorphism with growth traits in sheep. For example, Hajihosseinlo et al. (2013), Tahmoorespur et al. (2009), Negahdary et al. (2013) and Gholibeikifard et al. (2013) observed significant effects of the IGF-I gene polymorphism on several growth traits in Makooei and Baluchi sheep. Moreover, Hajihosseinlo et al. (2013) investigated the association of nucleotide substitution in the IGFI gene with several body size traits in sheep. It should be pointed out that the abovementioned studies were conducted only in Iranian sheep breeds. Therefore, there is a lack of information about these associations in sheep breeds in other countries, especially in Europe. To our knowledge, until now only Proskura and Szwczuk (2014) had investigated effects of single-nucleotide polymorphism (SNP) in the third exon of the IGF-I gene on growth traits in Pomeranian Coarsewool sheep in Poland and there was no association study involving the $I G F-I$ gene and body size traits in countries other than Iran, nor any subjective assessment of body muscle and fat class in sheep. Interestingly, in cattle, several authors have found significant associations between the IGF-I gene polymorphism and growth traits (e.g. De la Rosa Reyna et al., 2010; Ge et al., 2001; Li et al., 2004). Moreover, Zhang et al. (2008) reported significant effects of nucleotide substitution in the IGF-I gene on several body size traits in goats. Additionally, Gao et al. (2009) showed that the IGFBP-3 gene polymorphism was associated with chosen body measurements in Chinese beef cattle.

Despite the fact that the $I G F-I$ gene plays a role in the growth of an organism, it could also be directly or indirectly associated with other traits, i.e. carcass and meat quality traits, as SNPs in this gene could be markers in linkage with causative mutations in other genes. For example, Behzadi et al. (2015) investigated effects of the IGF-I gene polymorphism on carcass traits in sheep. Moreover, Sun et al. (2014) studied correlations between the IGF-I gene expression and carcass and net meat weight in Hu sheep. Siadkowska et al. (2006) and Curi et al. (2005) observed associations between the IGF-I gene polymorphism and several carcass traits in cattle. In the case of meat quality traits, there have only been a few association analyses in sheep. Behzadi et al. (2015) investigated effects of the IGF-I gene on the level of triglycerides and cholesterol in blood. Su et al. (2014) analysed relationships between the IGF-I gene expression and diameter and density of muscle fibre as well as muscle tenderness in Hu sheep. In pigs, Wang et al. (2009, 2010) observed effects of the IGFBP-3 and IGFBP-5 gene polymorphisms on meat colour and $\mathrm{pH}$ of various meat cuts, respectively.

Among many factors affecting growth, body size, carcass and meat quality traits, effects of many candidate genes still need to be investigated, especially in sheep. Identification of associations between candidate gene polymorphisms and the abovementioned attributes can provide useful markers for selection of economically favourable traits. However, little is known about the effect of the IGF-I gene polymorphism on growth, body size, carcass and meat quality traits in sheep, especially in European breeds. Moreover, to our knowledge no previous association studies between IGF-I genotypes and many important carcass and meat quality traits in sheep have been conducted. Therefore, the aims of the present study were to investigate the polymorphism in the $5^{\prime}$ flanking region of the IGF-I gene and to evaluate the associations between SNP in this gene and a wide spectrum of growth, body size, carcass and meat quality traits in Coloured Polish Merino sheep.

\section{Materials and methods}

In total, 305 purebred Coloured Polish Merino lambs of both sexes were investigated. The Coloured Polish Merino is a sheep breed used for its wool and meat. It is included in the Programme of Farm Animal Genetic Resources Conservation supervised by the National Research Institute of Animal Production (NRIAP) in Poland. Sheep were kept indoors, but they also grazed on a pasture six times a week at the NRIAP Experimental Station Kołuda Wielka. Lambs were sired by nine different rams and were produced during a period of 3 years - from 2011 to 2013. Suckling lambs were fed dry granulated mash and meadow hay ad libitum. Procedures involving animals were approved by the local animal research ethics committee and the local veterinary service.

Growth data (body weight on the second, 30th, 56th and 78th days of life) were collected for 277 male and female lambs. Moreover, the average daily gains between the second and 30th, 30th and 56th, and 56th and 78th days were calculated.

In total, 305 male and female lambs were ultrasonically (USG) scanned according to the procedure described by Krupiński et al. (2009) using an Aloka SSD-900 device with a UST-5818-5 transducer (B-5MHz). In brief, USG examination of a cross section of the longissimus dorsi $(L D)$ muscle was performed on the right body side perpendicularly to the spine axis behind the last thoracic vertebrae. Measurements of width, depth and area of the $L D$ muscle and fat depth over $L D$ muscle were performed on USG images with the use of MultiScan ver. 18.03 software.

In total, 106 ram lambs were chosen for slaughter during the 3 experimental years. Before slaughter, the following body measurements were carried out on lambs: withers height, chest depth, body length, shoulder width, hip width and leg depth. The measurements were taken while the lambs were in a standing position, according to the methodology of Kawęcka (2013). Subjective evaluations of muscling as well as fatness with the use of a five-point system (ranges 
from one to five with a 0.5 precision, with a value of five being the meatiest or fattiest class) were undertaken in the lumbar part of the spine behind the last rib near the kidney according to the methodology of Jarrige (1988). Slaughters, carcass cutting and leg dissection took place three or four times a year from March to April according to the methodology of Nawara et al. (1963) and Krupiński et al. (2009) in the abattoir of the NRIAP Experimental Station Kołuda Wielka. Mean age at slaughter was 105 days (SD 4.2, range 92-119 days). In brief, lambs were weighed twice: 1 day before slaughter (final weight) and on the day of slaughter (pre-slaughter weight). Then animals were electrically stunned, exsanguinated and skinned. Subsequently, carcasses were weighed (hot carcass weight) and maintained in a chilling room, where the temperature was held at approximately $4^{\circ} \mathrm{C}$ for $18 \mathrm{~h}$. After chilling carcasses were weighed again (cold carcass weight) and the cold carcass dressing out was calculated by dividing the cold carcass weight by the preslaughter weight and multiplying by 100 . In the next step, carcasses were visually graded for muscle and fat class on a nine-point scale (with the value of nine being the meatiest or fattiest class) according to the methodology implemented at ram evaluation stations in Germany as described by Krupiński et al. (2009). Conformation and muscling were assessed on each of the three parts of carcass separately: on the fore part of the carcass consisting of middle neck and shoulder, on the full loin part including rib and loin, and on the leg part. The evaluation of fatness involved two traits: kidney fat class and external fatness of carcass class. Carcasses were also categorised in terms of muscle and fat class according to the EUROP grading system as described by Krupiński et al. (2009). Subsequently, the following dimensions of carcasses were measured according to the methodology of Nawara et al. (1963): carcass length, breast depth, breast width, rump width, rump girth, leg depth, leg length index and loin width. Then carcasses were halved, and the right carcass side was weighed and taken for further examination. The kidney, kidney fat and the rest of the diaphragm were removed. At first, the right carcass side was divided into three parts: the fore part of the carcass, the full loin part, and the leg part, and each part was weighed. Subsequently, these three parts were divided into the following cuts: scrag, middle neck, shoulder, breast and flank, rib, loin, tenderloin, leg, fore shank, and hind shank, according to the methodology of Nawara et al. (1963). All cuts were weighed. On the surface, where a rib was cut from a loin, width, depth and the area of the eye of loin and fat depth over the eye of loin were measured. Moreover, fat depth over the ribs in the thickest point of this layer was recorded. The leg was dissected for three tissues: muscles, bones and fat, which were weighed separately and a yield of each tissue in the leg was calculated.

Furthermore, loin muscles from the right carcass side were vacuum-packed and transported to the Institute of Agricultural and Food Biotechnology (Poland), where meat quality analyses were undertaken. The $\mathrm{pH}$ measurements were performed on samples of longissimus lumborum ( $L L)$ muscle $24 \mathrm{~h}$ post mortem ( $\mathrm{pH} 24 \mathrm{~h})$ using a German Mettler Toledo $1140 \mathrm{pH}$ meter with an integrated Mettler Toledo electrode (ISO 2917, 2001). Results were averaged from the three measurements per one sample. For an instrumental evaluation of meat colour, steaks (thickness approximately $10 \mathrm{~mm}$ each) were cut crosswise in the direction of the $L L$ muscle fibres and exposed to daylight or electric light for $15 \mathrm{~min}$. The values of reflectance coordinates $-L^{*}$ (lightness), $a^{*}$ (redness) and $b^{*}$ (yellowness) - were gathered using a Konica Minolta chronometer CR-400. Drip loss value was measured on the $L L$ muscle. Before, the test samples were weighed, individually packed in plastic bags, held at $4{ }^{\circ} \mathrm{C}$ for $48 \mathrm{~h}$ and weighed again. The value of drip loss was defined as a percentage weight loss calculated from the difference between initial and final weight of the sample. Water, intramuscular fat and total protein content percentages were determined on minced samples of the $L L$ muscles according to the methods described in ISO 1442 (2000), 1444 (2000) and PN-75/A-04018 (2000), respectively, using a Kjeltec system 1002 distilling unit and a Soxtherm device manufactured by Gerhardt Analytical Systems. Water holding capacity was investigated in minced $L L$ muscle samples according to the method devised by Grau and Hamm (1952) with later modifications made by Pohja and Ninivaara (1957). Cooking loss was analysed on samples of the longissimus dorsi $(L D)$ muscle. First of all, the samples were weighed, then packed in plastic bags, heated in water until they reached $75^{\circ} \mathrm{C}$ in the centre of the sample and were weighed again at the end of the analysis. The value of cooking loss was calculated from a difference in sample weights recorded before and after the process of heating and was expressed as a percentage. Furthermore, shear force was determined in cooked and cooled-down samples of lamb loin. For this purpose cylindershaped samples ( $2.5 \mathrm{~cm}$ diameter) of the $L D$ muscle were extracted parallel to the direction of muscle fibres and were subjected to shear force $\left(\mathrm{N} \mathrm{cm}^{-2}\right)$ measurement with the use of a Zwick Roell ZO with a $0.5 \mathrm{kN}$ head and Warner Bratzler device with a blade speed of $100 \mathrm{~mm} \mathrm{~min}^{-1}$. Moreover, subjective visual evaluations of meat colour and marbling were performed on the $L L$ muscle by a team of five people using an eight-point scale for colour, where one is related to the lightest and eight is related to the darkest colour, and a fourpoint scale for marbling, with a score of one relating to minor marbling and four relating to the greatest marbling. Subjective sensory evaluation of aroma, succulence, tenderness and flavour were performed on boiled $L D$ muscle using a fivepoint scale for each trait according to the methodology of Baryłko-Pikielna (1975), where one was related to bad levels and five was related to very good levels of the trait.

Total genomic DNA was purified from the blood using a MasterPure $^{\mathrm{TM}}$ DNA Purification Kit for Blood Version II (Epicentre, USA). Polymorphism in the $5^{\prime}$ flanking region of the ovine $I G F-I$ gene was detected with the use of the polymerase chain reaction restriction fragment length poly- 
morphism (PCR-RFLP) method. A fragment of the ovine $I G F-I$ gene was amplified using primers reported by Ge et al. (1997). DNA amplifications were performed in a Mastercycler Pro (Eppendorf AG, Germany) in $20 \mu \mathrm{L}$ reaction volume containing $50 \mathrm{ng}$ of genomic DNA, 5 pmol of each primer (forward and reverse), $200 \mu \mathrm{M}$ of each dNTP and $1 \mathrm{U}$ DreamTaq DNA polymerase (Thermo Scientific, USA) in a one-fold DreamTaq reaction buffer. The temperature profile of the reaction consisted of denaturation at $94^{\circ} \mathrm{C}$ for $2 \mathrm{~min}$, followed by 30 amplification cycles, including denaturation at $94^{\circ} \mathrm{C}$ for $30 \mathrm{~s}$, annealing at $66^{\circ} \mathrm{C}$ for $30 \mathrm{~s}$ and extension at $72^{\circ} \mathrm{C}$ for $30 \mathrm{~s}$, with a final 5 min extension step at $72^{\circ} \mathrm{C}$. The PCR reaction products were digested with $4 \mathrm{U}$ of HaeII (NEB, UK) restriction enzyme (Yilmaz et al., 2005) for $2 \mathrm{~h}$ at $37^{\circ} \mathrm{C}$. Digested PCR products were separated on $2 \%$ agarose gels in $1 \times \mathrm{TBE}$ (Tris-borate-EDTA) buffer for $90 \mathrm{~min}$ at $120 \mathrm{~V}$ and visualised by Midori Green (Nippon Genetics, Germany) staining. PCR products representing the $\mathrm{AA}$ and $\mathrm{AB}$ genotypes were cleaned up with the use of an ExoSAP-IT ${ }^{\circledR}$ Affymetrix (USA) and sequenced in both directions in Genomed, Poland. Allele and genotype frequencies in the IGF-I locus were calculated. Furthermore, observed and expected heterozygosity as well as the HardyWeinberg equilibrium test calculations were made in the Arlequin 3.5.1.2 (Excoffier and Lischer, 2010).

An association analysis was performed between IGF-I genotypes and growth traits using the MIXED procedure of the SAS software package (SAS, 2008). The following mixed effect model I was applied:

$Y_{i j k l m}=\mu+a_{i}+b_{j}+c_{k}+d_{l}+f_{m}+e_{i j k l m}$,

where $Y_{i j k l m}$ is the performance of the $n$th individual lamb for each trait of interest, $\mu$ is the general mean for each trait of interest, $a_{i}$ is the fixed effect of the $i$ th $I G F-I$ genotype ( $i=\mathrm{AA}, \mathrm{AB}), b_{j}$ is the fixed effect of the $j$ th sex $(j=$ male, female), $c_{k}$ is the fixed effect of the $k$ th litter size $(k=1$, single; 2 , twin and only one lamb born with triplet litter size was also included), $d_{l}$ is the fixed effect of the $l$ th year of observation $(l=2011,2012,2013), f_{m}$ is the random effect of the $m$ th sire $(m=$ sire $1,2, \ldots 9)$ and $e_{i j k l m}$ is the random error. For all variables two-way interactions between fixed effects were tested in the model; however, they did not have a significant effect on investigated traits and were therefore excluded from the final model.

An association analysis between $I G F-I$ genotypes and body size traits as well as IGF-I genotypes and slaughter traits was undertaken with the use of the model I described above without the effect of the sex because only male lambs were investigated. Moreover, final weight and cold carcass weight were found to be significant and were included in the final models as a covariate for live and post mortem attributes, respectively. Weight was not included as the covariate in the model where the $Y$ variable was the final weight, pre-slaughter weight, a tissue proportion or dressing out. In the case of final and pre-slaughter weight, slaughter age was found to be significant and was included as the covariate in the model. Furthermore, final weight was fitted in the model as the covariate for hot and cold carcass weight. For all variables, two-way interactions between fixed effects were tested in the model but were not significant for almost all of the traits, with the exception of withers height, chest depth, leg depth (body measurement), scrag weight, and hot and cold carcass weight; therefore, they were included in the models only for the abovementioned traits, but not for all other characteristics.

Moreover, an association of IGF-I genotypes with USG measurements of the $L D$ muscle was also estimated with the use of the model I described above; however, slaughter age was included as the covariate. For all variables, two-way interactions between fixed effects were tested in the model but did not have a significant effect on investigated traits, with the exception of fat depth over the $L D$ muscle; therefore, it was fitted in the model only for this trait. An association analysis between IGF-I genotypes and meat quality traits was performed with the use of the model I described above without the effect of sex and litter size. For all variables, two-way interactions between fixed effects were tested in the model but did not show any significant effect on investigated traits; therefore, they were not included in the final model. In the case of each model, when a genotype was shown to be statistically significant, the significance of deviations was verified with the Tukey-Kramer test.

Associations of IGF-I genotypes with subjective assessment of live animal and carcass traits were analysed with the use of the GENMOD procedure of the SAS software package (SAS, 2008). The generalised linear model included the fixed effects of IGF-I genotype, litter size, year of observation and sire. Moreover, final weight and cold carcass weight were found to be significant and were fitted in the model as the covariates for live and post mortem attributes, respectively.

\section{Results}

\subsection{Identification of alleles}

PCR-RFLP analysis of polymorphism in the $5^{\prime}$ flanking region of the IGF-I gene in Coloured Polish Merino sheep revealed two alleles, named $A$ and $B$, and only two genotypes: $\mathrm{AA}$ and $\mathrm{AB}$. The HaeII digested allele A amplicon, while allele B remained undigested. Sequence analysis showed that two SNPs differed allele A from allele B. The first polymorphism covered G/C transversion, while the second covered G/A transition, at positions 85 and 87 , respectively (nucleotide positions are relative to the first nucleotide in the sequence; GenBank no. LC151296.1). 
Table 1. $I G F-I$ allele and genotype frequencies (\%) in Coloured Polish Merino sheep.

\begin{tabular}{lcr}
\hline \multicolumn{2}{c}{$\begin{array}{c}\text { Allele/genotype } \\
(n=305)\end{array}$} & $\begin{array}{r}\text { Frequency } \\
(\%)\end{array}$ \\
\hline \multirow{2}{*}{ Allele } & $\mathrm{A}$ & $91.6 \%$ \\
& $\mathrm{~B}$ & $8.4 \%$ \\
\hline \multirow{2}{*}{ Genotype } & $\mathrm{AA}$ & $83.3 \%$ \\
& $\mathrm{AB}$ & $16.7 \%$ \\
\hline
\end{tabular}

\subsection{Allele and genotype frequencies}

$I G F-I$ allele and genotype frequencies in the investigated breed are shown in Table 1. The A allele was predominant $(91.6 \%)$, while the B allele occurred with the frequency of $8.4 \%$. The most frequent group was AA homozygotes $(83.3 \%)$, while $16.7 \%$ of lambs carried the AB genotype. The value of observed heterozygosity $\left(H_{\mathrm{o}}\right)$ was equal to 0.167 , and was higher than the value of expected heterozygosity $\left(H_{\mathrm{e}}\right)$, which amounted to 0.153 . The population was in the Hardy-Weinberg equilibrium $(P=0.247)$.

\subsection{Effect of the IGF-I gene polymorphism on traits measured in live animals}

Mixed-model association analyses of the $I G F-I$ genotypes were performed for body weights, average daily gains, body measurements and ultrasound $L D$ muscle measurements. Effects of the IGF-I gene polymorphism on these traits in Coloured Polish Merino sheep are presented in Tables 24. None of the analyses showed any significant effect of the $I G F-I$ genotype on the abovementioned characteristics; however, the $I G F-I$ gene polymorphism tended to be associated with $L D$ muscle width $(P=0.063)$. AB heterozygous lambs had wider $L D$ muscle $(0.14 \mathrm{~cm})$ than in AA homozygotes (Table 4). Results of the generalised linear model analyses of the $I G F-I$ genotype effect on body muscle and fat class are presented in Table 7. No associations between the IGF-I gene polymorphism and these traits were found.

\subsection{Effect of the IGF-I gene polymorphism on carcass traits}

Tables 5 and 7 show the results of association analyses between the $I G F-I$ gene polymorphism and carcass traits in Coloured Polish Merino sheep. IGF-I genotype was associated with fore shank weight $(P=0.006)$. Heterozygous lambs had heavier fore shank $(4.3 \%)$ than AA homozygous animals. Furthermore, the $I G F-I$ genotype was found to have highly significant effects on kidney fat class $(P=0.002)$ and EUROP fat class $(P=0.005)$ and a significant effect on external fatness of carcass class $(P=0.038)$. No significant associations between $I G F-I$ genotype and other investigated carcass traits were detected.

\subsection{Effect of the IGF-I gene polymorphism on meat quality traits}

Results of association analyses of the IGF-I gene polymorphism with meat quality traits in Coloured Polish Merino sheep are presented in Table 6. The IGF-I gene polymorphism was significantly associated with drip loss $(P=0.049)$. Meat from AA homozygous lambs was characterised by lower average drip loss $(-0.86 \%)$ than meat from heterozygotes AB. Moreover, the $I G F-I$ gene polymorphism had a significant effect on the subjective assessment of meat colour $(P=0.043)$. AA homozygous ram lambs had meat characterised by the higher average value of this trait (0.34 point) when compared to meat form heterozygotes $\mathrm{AB}$. Furthermore, the $I G F-I$ genotype tended to be associated with the flavour $(P=0.067)$.

\section{Discussion}

In the present study, polymorphism in the $5^{\prime}$ flanking region of the $I G F-I$ gene and its association with growth, body size, carcass and meat quality traits in Coloured Polish Merino sheep were analysed. Two alleles, named A and B, and only two genotypes, AA and AB, were detected. The A allele was predominant $(91.6 \%)$, which consequently resulted in the higher frequency of the AA homozygotes $(83.3 \%)$ than the AB heterozygotes. These results are consistent with the study of Yilmaz et al. (2005), who also reported a high frequency of the A allele and the AA genotype (89 and $77 \%$, respectively) in Polypay sheep. Conversely, Tahmoorespur et al. (2009) and Nazari et al. (2016) detected lower frequencies of the AA genotype (45 and $28 \%$ ) and identified the BB homozygotes (9 and $34 \%$ ) in Baluchi and Zandi sheep, respectively. Furthermore, Hajihosseinlo et al. (2013) and Kazemi et al. (2011) identified three genotypes in this locus in Makooei (AA - 52\%, AG - 42\% and GG - 6\%) and Zel (AA $-47 \%, \mathrm{AB}-47 \%$ and $\mathrm{BB}-6 \%$ ) sheep, respectively. He et al. (2012) found two SNPs in the $5^{\prime}$ regulatory region of the $I G F-I$ gene in four sheep breeds in China. Dorset and Texel sheep were characterised by very high AA genotype frequencies (100 and $93.8 \%$, respectively) and a lack of the BB homozygotes. Conversely, percentage frequency of the AA genotype in Hu sheep was low (37.9\%) and moderate in Small-Tailed Han sheep $(64.6 \%)$ when compared to Dorset and Texel sheep in the study of He et al. (2012). Moreover, Scatà et al. (2010) identified two SNPs (g.855G > C and $g .857 \mathrm{G}>\mathrm{A}$ ) in the $5^{\prime}$ UTR of the $I G F-I$ gene in Gentile di Puglia, Altamurana and Sarda sheep breeds. Proskura and Szewczuk (2014) analysed the g.271C $>\mathrm{T}$ in the third exon of the IGF-I gene and they found that the $\mathrm{T}$ allele was predominant in Pomeranian Coarsewool sheep (79.5\%). Similarly, Scatà et al. (2010) also observed high frequencies of the T allele in Gentile di Puglia (61.3\%) and Sarda (54.5\%), but slightly lower in Altamurana sheep (43.1\%). Conversely, Gholibeikifard et al. (2013) reported a very low frequency of 
Table 2. Results of association analysis between IGF-I genotypes and growth traits - LSM \pm SE (standard error) - in Coloured Polish Merino sheep.

\begin{tabular}{lrrrr}
\hline Trait & Unit & \multicolumn{2}{c}{ LSM $^{*} \pm$ SE } & \multirow{2}{*}{$P$ value } \\
\cline { 3 - 4 } & & AA & AB \\
\hline$N$ & & 227 & 50 & 0.783 \\
Body weight on second day of life & $\mathrm{kg}$ & $5.11 \pm 0.10$ & $5.08 \pm 0.13$ & 0.527 \\
Body weight on 30th day of life & $\mathrm{kg}$ & $12.80 \pm 0.18$ & $12.61 \pm 0.28$ & 0.545 \\
Body weight on 56th day of life & $\mathrm{kg}$ & $19.30 \pm 0.32$ & $19.04 \pm 0.45$ & 0.511 \\
Body weight on 78th day of life & $\mathrm{kg}$ & $26.56 \pm 0.46$ & $26.21 \pm 0.60$ & 0.505 \\
Average daily gain between second and 30th days of life & $\mathrm{g}$ & $255.36 \pm 3.95$ & $250.10 \pm 7.22$ & 0.789 \\
Average daily gain between 30th and 56th days of life & $\mathrm{g}$ & $249.69 \pm 6.75$ & $247.59 \pm 8.89$ & 0.796 \\
Average daily gain between 56th and 78th days of life & $\mathrm{g}$ & $328.00 \pm 8.13$ & $324.75 \pm 12.44$ & 16 \\
\hline$N$ & & & 90 & \\
Final weight & $\mathrm{kg}$ & $34.64 \pm 0.54$ & $33.77 \pm 1.16$ & 0.487 \\
Pre-slaughter weight & $\mathrm{kg}$ & $32.40 \pm 0.51$ & $31.80 \pm 1.07$ & 0.601 \\
\hline
\end{tabular}

* LSM is least squares mean.

Table 3. Results of association analysis between IGF-I genotypes and body size traits (LSM $\pm \mathrm{SE}$ ) in Coloured Polish Merino sheep.

\begin{tabular}{lrrrr}
\hline Trait & Unit & \multicolumn{2}{c}{ LSM $^{*} \pm \mathrm{SE}$} & \multirow{2}{*}{$P$ value } \\
\cline { 3 - 4 } & & $\mathrm{AA}$ & $\mathrm{AB}$ & \\
\cline { 3 - 4 }$N$ & & 90 & 16 & \\
Withers height & $\mathrm{cm}$ & $57.9 \pm 0.48$ & $59.5 \pm 0.98$ & 0.128 \\
Chest depth & $\mathrm{cm}$ & $25.5 \pm 0.37$ & $25.8 \pm 0.70$ & 0.671 \\
Body length & $\mathrm{cm}$ & $57.2 \pm 0.47$ & $56.9 \pm 0.80$ & 0.771 \\
Shoulder width & $\mathrm{cm}$ & $19.21 \pm 0.13$ & $19.0 \pm 0.28$ & 0.425 \\
Hip width & $\mathrm{cm}$ & $15.5 \pm 0.14$ & $15.6 \pm 0.23$ & 0.854 \\
Leg depth & $\mathrm{cm}$ & $20.4 \pm 0.16$ & $20.1 \pm 0.34$ & 0.396 \\
\hline
\end{tabular}

${ }^{*}$ LSM is least squares mean.

the $\mathrm{T}$ allele ( $5 \%$ ) in Baluchi sheep and they did not find TT homozygotes. Niżnikowski et al. (2015) investigated polymorphism in the third exon of the IGF-I gene in different sheep breeds in Poland and they detected the T allele only in Charollais ewes. To summarise, allele and genotype frequencies in the IGF-I locus vary between different sheep breeds; therefore, studies covering other sheep breeds should be continued.

The IGF-I locus was characterised by a low genetic diversity in the investigated Coloured Polish Merino sheep population. The value of observed heterozygosity $(0.167)$ was slightly higher than the value of expected heterozygosity (0.153). Moradian et al. (2013) also observed two alleles in the IGF-I locus in Makooei sheep; nevertheless, values of $H_{\mathrm{o}}$ and $H_{\mathrm{e}}$ were higher: 0.42 and 0.40 , respectively. The Coloured Polish Merino sheep population was in the Hardy-Weinberg equilibrium $(P=0.247)$, indicating no selection for investigated IGF-I locus. Similarly, Negahdary et al. (2013), who investigated polymorphism of the $5^{\prime}$ flanking region of the $I G F-I$ gene, reported that the population of Makooei sheep was in the Hardy-Weinberg equilibrium $(P>0.05)$. Conversely, Nazari et al. (2016), who studied the $I G F-I$ locus in Zandi sheep, showed that this population was not in the Hardy-Weinberg equilibrium $(P<0.01)$.

The $I G F-I$ gene affects many important processes in an organism, growth being among them (Akers, 2006; Burgos and Cant, 2010). Circulating IGF-I concentration has an impact on fetal and neonatal size and postnatal growth in several species (Baker et al., 1993; Breier et al., 1988; Duclos et al., 1999; Yakar et al., 2002; Zapf and Froesch, 1999). However, association analysis did not show significant effects of the $I G F-I$ gene polymorphism on growth traits in Coloured Polish Merino sheep. Similarly, Nazari et al. (2016) did not find significant associations between SNP in the $5^{\prime}$ flanking region of the $I G F-I$ gene and growth traits in Zandi sheep. Also, Proskura and Szewczuk (2014) did not show any relationships between the $\mathrm{C} / \mathrm{T}$ substitution $(\mathrm{g} .271 \mathrm{C}>\mathrm{T}$ ) in the $I G F-I$ gene and growth traits in Pomeranian Coarsewool sheep in Poland. Moreover, Gholibeikifard et al. (2013) did not observe the effects of SNP, located in the third exon of the $I G F-I$ gene, on growth traits in Baluchi sheep. Conversely, Tahmoorespur et al. (2009) showed significant associations of the $I G F-I$ gene polymorphism in the $5^{\prime}$ flanking region with average daily gain (ADG) from birth to weaning in Baluchi sheep. Heterozygous lambs had higher ADG from birth to weaning than homozygotes AA and BB. Furthermore, Hajihosseinlo et al. (2013) observed significant effects of nucleotide variation in the $5^{\prime}$ flanking region of the $I G F-I$ gene with several growth traits in Makooei sheep: birth weight (BW), weaning weight (WW), 6-month weight (SW) and average daily gains from birth to weaning (GBW). Additionally, a significant association of polymorphism in the $5^{\prime}$ flanking region of the $I G F-I$ gene with $\mathrm{BW}, \mathrm{WW}, \mathrm{SW}$, breeding value estimated for body weight in the sixth month of life (EBV 6MW), GBW and average daily gains from the 
Table 4. Results of association analysis between IGF-I genotypes and live ultrasound measurements of the $L D$ muscle (LSM $\pm \mathrm{SE}$ ) in Coloured Polish Merino sheep.

\begin{tabular}{llrrr}
\hline Trait & Unit & \multicolumn{2}{c}{ LSM $^{*} \pm \mathrm{SE}$} & \multirow{2}{*}{$P$ value } \\
\cline { 3 - 4 } & & $\mathrm{AA}$ & $\mathrm{AB}$ & \\
\cline { 3 - 4 }$N$ & & 254 & 51 & \\
$L D$ muscle depth & $\mathrm{cm}$ & $2.24 \pm 0.03$ & $2.27 \pm 0.05$ & 0.530 \\
$L D$ muscle width & $\mathrm{cm}$ & $4.90 \pm 0.05$ & $5.04 \pm 0.07$ & 0.063 \\
$L D$ muscle area & $\mathrm{cm}^{2}$ & $7.83 \pm 0.19$ & $8.04 \pm 0.26$ & 0.341 \\
Fat depth over $L D$ muscle & $\mathrm{cm}$ & $0.184 \pm 0.004$ & $0.183 \pm 0.005$ & 0.855 \\
\hline
\end{tabular}

* LSM is least squares mean.

sixth month to the ninth month of life (GSN) were found in Makooei sheep (Negahdary et al., 2013). AG heterozygous Makooei sheep had higher values of the traits EBV $6 \mathrm{MW}, 6 \mathrm{MW}$ and WW than homozygotes. Conversely, AA homozygous sheep had higher BW and GBW (Negahdary et al., 2013). Furthermore, Sun et al. (2014), who investigated the effects of different factors on the level of the IGF-I gene expression and its associations with growth traits, observed a positive correlation of this gene's expression with body weight in $\mathrm{Hu}$ sheep. Other authors analysed the effects of the $I G F-I$ gene polymorphisms with growth traits in other livestock species. For example, Ge et al. (2001) showed associations between variation in the $I G F-I$ gene and growth traits in Angus cattle and suggested that this polymorphism could have an impact on gene transcription and consequently on animal phenotype. Szewczuk et al. (2013) reported effects of two SNPs in the IGF-I gene on body weight in the second month of life in calves and average daily gains in the periods from the first to the second months and from the second to the third months of life and for the whole rearing period. Zhang et al. (2008) investigated polymorphism of the $I G F-I$ gene and its association with growth and body size traits in Nanjiang Huang goats. They found a significant effect of G/C substitution on birth weight, body weight at 6 months, body weight at 12 months, heart girth at 2 months, body length at 6 months, wither height at 6 months, wither height at 12 months and heart girth at 12 months in the goats. Concluding, there are analyses that confirm associations of the $I G F$ $I$ gene polymorphisms with growth traits in sheep and other livestock species; however, there are other reports that are opposite to these findings. The growth of animals is a complex process that is under the control of several genes and environmental factors. Moreover, the effects of the IGF-I gene polymorphism on growth traits seem to depend on sheep breed. Therefore, before introducing DNA tests in sheep breeding, additional analyses of this gene's polymorphism and its association with growth traits in different sheep breeds should be undertaken.

The IGF-I hormone plays a crucial role in the postnatal linear growth of animals (e.g. Yakar et al., 2002; Zapf and Froesch, 1999). In this study an association of the $I G F-I$ gene polymorphism with body size traits and subjective assessment of body muscle and fat class in Coloured Polish Merino sheep was investigated; however, the effects of IGF-I genotypes on these traits were not significant. Conversely, Hajihosseinlo et al. (2013), who investigated associations of the $I G F-I$ gene polymorphism in the $5^{\prime}$ flanking region with such body size traits as height and length of body, wither height, chest width and rump length in Makooei sheep, found a significant effect of this gene's genotypes on sheep body length. Moreover, Chelongar et al. (2014) observed a significant effect of SNP in the first exon of the $I G F-I$ gene on fat-tail fat thickness (the thick rump). AA homozygotes were superior in terms of this trait, whereas GG male lambs had the lowest fat thickness. The associations of nucleotide variation in the first exon of the $I G F-I$ gene with tail length and width (rump length and width) in Makooei sheep was not significant (Chelongar et al., 2014). Associations between the IGF-I gene polymorphism and body size traits were also investigated in other livestock species. For example, Zhang et al. (2008) found the significant effects of $\mathrm{G} / \mathrm{C}$ substitution in the fourth intron of the $I G F-I$ gene on heart girth at 2 months, body length at 6 months, wither height at 6 months, wither height at 12 months and heart girth at 12 months in Nanjiang Huang goats. Gao et al. (2009) showed that the polymorphism in the IGFBP-3 locus was associated with rump width and heart girth at 24 and 36 months in Chinese beef cattle. Furthermore, Mullen et al. (2011) reported that SNP in the IGF-I gene (IGF 1i6; G allele) was positively associated $(P<0.05)$ with body condition score in Holstein-Friesian dairy cattle, while Lynch et al. (2010) showed a relationship between IGF $1 \mathrm{i} 2$ and body condition score at calving in a cohort of 241 dairy cows. IGF-I protein affects longitudinal bone growth by promoting osteoblast division and proliferation. Furthermore, it regulates muscle growth by enhancing myocyte differentiation and multiplication and has an impact on cartilage growth by increasing chondrocyte colony formation (Duclos et al., 1999; Yakar et al., 2002; Zapf and Froesch, 1999). It should be pointed out that there is limited information about effects of the IGF-I gene polymorphism on body size traits, especially in sheep. Moreover, to our knowledge it was the first association analysis of $I G F-I$ genotypes and subjective 
Table 5. Results of association analysis between IGF-I genotypes and carcass traits (LSM \pm SE) in Coloured Polish Merino sheep.

\begin{tabular}{|c|c|c|c|c|}
\hline \multirow[t]{2}{*}{ Trait } & \multirow[t]{2}{*}{ Unit } & \multicolumn{2}{|c|}{$\mathrm{LSM}^{*} \pm \mathrm{SE}$} & \multirow[t]{2}{*}{$P$ value } \\
\hline & & AA & $\mathrm{AB}$ & \\
\hline$N$ & & 90 & 16 & \\
\hline Hot carcass weight & $\mathrm{kg}$ & $13.97 \pm 0.11$ & $13.91 \pm 0.16$ & 0.685 \\
\hline Cold carcass weight & $\mathrm{kg}$ & $13.60 \pm 0.10$ & $13.56 \pm 0.15$ & 0.796 \\
\hline Cold carcass dressing out & $\%$ & $43.72 \pm 0.32$ & $43.38 \pm 0.51$ & 0.484 \\
\hline \multicolumn{5}{|l|}{ Carcass parts } \\
\hline Right carcass side weight & $\mathrm{kg}$ & $6.67 \pm 0.02$ & $6.61 \pm 0.04$ & 0.170 \\
\hline Fore part of the carcass weight & $\mathrm{g}$ & $2629 \pm 13.7$ & $2607 \pm 28.0$ & 0.453 \\
\hline Full loin part weight & $\mathrm{g}$ & $1711 \pm 9.9$ & $1690 \pm 20.4$ & 0.339 \\
\hline Leg part weight & $\mathrm{g}$ & $2214 \pm 10.3$ & $2212 \pm 18.1$ & 0.884 \\
\hline \multicolumn{5}{|l|}{ Carcass dimensions } \\
\hline Carcass length & $\mathrm{cm}$ & $55.7 \pm 0.27$ & $56.0 \pm 0.43$ & 0.468 \\
\hline Breast depth & $\mathrm{cm}$ & $23.4 \pm 0.09$ & $23.6 \pm 0.18$ & 0.232 \\
\hline Breast width & $\mathrm{cm}$ & $21.9 \pm 0.13$ & $21.6 \pm 0.24$ & 0.278 \\
\hline Rump width & $\mathrm{cm}$ & $22.4 \pm 0.09$ & $22.3 \pm 0.16$ & 0.760 \\
\hline Rump girth & $\mathrm{cm}$ & $59.0 \pm 0.14$ & $59.1 \pm 0.28$ & 0.773 \\
\hline Leg depth & $\mathrm{cm}$ & $17.0 \pm 0.12$ & $17.3 \pm 0.21$ & 0.185 \\
\hline Leg length index & $\mathrm{cm}$ & $24.7 \pm 0.20$ & $24.7 \pm 0.27$ & 0.867 \\
\hline Loins width & $\mathrm{cm}$ & $11.9 \pm 0.06$ & $12.0 \pm 0.13$ & 0.718 \\
\hline \multicolumn{5}{|l|}{ Carcass cuts } \\
\hline Scrag weight & $\mathrm{g}$ & $376.2 \pm 4.77$ & $365.8 \pm 9.30$ & 0.304 \\
\hline Middle neck weight & $\mathrm{g}$ & $531.8 \pm 7.09$ & $514.0 \pm 13.00$ & 0.187 \\
\hline Shoulder weight & $\mathrm{g}$ & $1050.3 \pm 7.13$ & $1042.4 \pm 13.00$ & 0.556 \\
\hline Fore shank weight & $\mathrm{g}$ & $307.1 \pm 2.21^{\mathrm{a}}$ & $320.9 \pm 4.6^{\mathrm{b}}$ & 0.006 \\
\hline Breast and flank weight & $\mathrm{g}$ & $1031.6 \pm 7.88$ & $1039.3 \pm 15.91$ & 0.647 \\
\hline Rib weight & $\mathrm{g}$ & $470.2 \pm 4.35$ & $460.0 \pm 9.02$ & 0.297 \\
\hline Loin weight & $\mathrm{g}$ & $515.3 \pm 6.27$ & $500.9 \pm 13.01$ & 0.304 \\
\hline Tenderloin weight & $\mathrm{g}$ & $58.2 \pm 0.88$ & $58.5 \pm 1.59$ & 0.846 \\
\hline Leg weight & $\mathrm{g}$ & $1816.2 \pm 9.36$ & $1806.4 \pm 16.16$ & 0.551 \\
\hline Hind shank weight & $\mathrm{g}$ & $400.3 \pm 3.10$ & $405.1 \pm 5.91$ & 0.441 \\
\hline \multicolumn{5}{|l|}{ Eye of loin } \\
\hline Width & $\mathrm{mm}$ & $55.1 \pm 0.35$ & $54.6 \pm 0.73$ & 0.461 \\
\hline Depth & $\mathrm{mm}$ & $29.6 \pm 0.25$ & $30.4 \pm 0.50$ & 0.137 \\
\hline Area & $\mathrm{cm}^{2}$ & $12.40 \pm 0.16$ & $12.42 \pm 0.34$ & 0.955 \\
\hline Fat depth over eye of short loin & $\mathrm{mm}$ & $2.29 \pm 0.09$ & $2.26 \pm 0.17$ & 0.861 \\
\hline \multicolumn{5}{|l|}{ Leg } \\
\hline Muscle tissue yield & $\%$ & $71.74 \pm 0.29$ & $71.78 \pm 0.56$ & 0.934 \\
\hline Fat tissue yield & $\%$ & $12.64 \pm 0.28$ & $12.26 \pm 0.55$ & 0.509 \\
\hline Bone tissue yield & $\%$ & $15.12 \pm 0.15$ & $15.52 \pm 0.33$ & 0.253 \\
\hline \multicolumn{5}{|l|}{ Other } \\
\hline Fat depth over ribs & $\mathrm{mm}$ & $4.56 \pm 0.16$ & $4.09 \pm 0.33$ & 0.199 \\
\hline
\end{tabular}

assessment of body muscle and fat class in sheep. Therefore, similar association analyses should be undertaken in other sheep breeds.
IGFs, their receptors and BPs play a crucial role in muscle growth and differentiation (Oksbjerg et al., 2004). In this study effects of the IGF-I gene polymorphism with ul- 
Table 6. Results of association analysis between IGF-I genotypes and meat quality traits (LSM \pm SE) in Coloured Polish Merino sheep.

\begin{tabular}{|c|c|c|c|c|}
\hline \multirow[t]{2}{*}{ Trait } & \multirow[t]{2}{*}{ Unit } & \multicolumn{2}{|c|}{$\mathrm{LSM}^{*} \pm \mathrm{SE}$} & \multirow[t]{2}{*}{$P$ value } \\
\hline & & AA & $\mathrm{AB}$ & \\
\hline$N$ & & 90 & 16 & \\
\hline Muscle $\mathrm{pH} 24 \mathrm{~h}$ post mortem & $\mathrm{pH}$ units & $5.68 \pm 0.01$ & $5.66 \pm 0.02$ & 0.629 \\
\hline \multicolumn{5}{|l|}{ Reflectance coordinates } \\
\hline$L^{*}$, lightness & units & $39.75 \pm 0.29$ & $39.57 \pm 0.66$ & 0.800 \\
\hline$a^{*}$, redness & units & $12.86 \pm 0.17$ & $12.69 \pm 0.28$ & 0.532 \\
\hline$b^{*}$, yellowness & units & $2.31 \pm 0.19$ & $2.08 \pm 0.35$ & 0.528 \\
\hline Water content & $\%$ & $73.35 \pm 0.18$ & $73.20 \pm 0.43$ & 0.752 \\
\hline Intramuscular fat content & $\%$ & $1.91 \pm 0.06$ & $1.81 \pm 0.14$ & 0.500 \\
\hline Total protein content & $\%$ & $23.59 \pm 0.16$ & $23.85 \pm 0.38$ & 0.523 \\
\hline \multicolumn{5}{|l|}{ Sensory evaluations } \\
\hline Aroma & $1-5$ & $4.46 \pm 0.02$ & $4.46 \pm 0.05$ & 0.944 \\
\hline Succulence & $1-5$ & $4.48 \pm 0.03$ & $4.50 \pm 0.06$ & 0.822 \\
\hline Tenderness & $1-5$ & $4.29 \pm 0.03$ & $4.25 \pm 0.08$ & 0.572 \\
\hline Flavour & $1-5$ & $4.43 \pm 0.03$ & $4.31 \pm 0.06$ & 0.067 \\
\hline \multicolumn{5}{|l|}{ Subjective visual evaluations } \\
\hline Colour & $1-8$ & $3.95 \pm \mathbf{0 . 0 6}^{\mathrm{a}}$ & $3.61 \pm 0.15^{b}$ & 0.043 \\
\hline Marbling & $1-4$ & $2.02 \pm 0.05$ & $2.01 \pm 0.11$ & 0.982 \\
\hline Water holding capacity & $\%$ & $34.27 \pm 0.33$ & $33.28 \pm 0.77$ & 0.238 \\
\hline Warner Bratzler shear force & $\mathrm{Ncm}^{-2}$ & $45.28 \pm 1.63$ & $44.13 \pm 3.90$ & 0.788 \\
\hline Drip loss & $\%$ & $2.47 \pm 0.24^{\mathrm{a}}$ & $3.33 \pm \mathbf{0 . 4 3}^{\mathrm{b}}$ & 0.049 \\
\hline Cooking loss (CL, \%) & $\%$ & $15.53 \pm 0.47$ & $15.07 \pm 0.99$ & 0.662 \\
\hline
\end{tabular}

Table 7. Results of association analysis between IGF-I genotypes and subjective assessment of live animal and carcass traits in Coloured Polish Merino sheep $(n=106)$.

\begin{tabular}{llc}
\hline Trait & Unit & $P$ value \\
\hline Live animal traits & & \\
\hline Muscle class & $1-5$ & 0.107 \\
Fat class & $1-5$ & 0.383 \\
\hline Carcass traits & & \\
\hline Conformation and muscle class of the fore part of carcass & $1-9$ & 0.373 \\
Conformation and muscle class of the full loin part of carcass & $1-9$ & 0.115 \\
Conformation and muscle class of the leg part of carcass & $1-9$ & 0.190 \\
Kidney fat class & $1-9$ & $\mathbf{0 . 0 0 2}$ \\
External fatness of carcass class & $1-9$ & $\mathbf{0 . 0 3 8}$ \\
EUROP conformation class & EUROP & 0.916 \\
EUROP fat class & $1,2,3 \mathrm{~L}, 3 \mathrm{H}, 4 \mathrm{~L}, 4 \mathrm{H}, 5$ & $\mathbf{0 . 0 0 5}$ \\
\hline
\end{tabular}

Values in bold are significant or highly significant.

trasound measurements of $L D$ muscle in Coloured Polish Merino sheep was not significant; however, it tended to be associated with the width of this muscle. Additionally, $L D$ muscle dimensions were also measured post mortem, but no sig- nificant associations between the $I G F-I$ gene polymorphism and these traits were showed. No other paper was found in the literature concerning association between IGF-I genotypes and ultrasound $L D$ muscle measurements in sheep. In- 
terestingly, in cattle the SNP in the IGF-I gene tended to be associated with the ultrasound $L D$ area $(P=0.06)$ (Curi et al., 2005). As the current study was the first association analysis of $I G F-I$ genotypes with ultrasound $L D$ muscle measurements in sheep, similar analysis in other sheep breeds should be undertaken in order to investigate possible breed effects on these traits.

In this study effects of $I G F-I$ genotypes on carcass traits in Coloured Polish Merino sheep were investigated. Among 40 traits, significant associations between IGF-I genotypes and fore shank weight, EUROP fat class, kidney fat class and external fatness of carcass class in Coloured Polish Merino ram lambs were found. Similarly, Behzadi et al. (2015) investigated effects of the $I G F-I$ gene polymorphism on fatrelated traits in Mehraban sheep. They observed a tendency for an association between SNP in this gene and dorsal fat thickness $(P=0.07)$; however, effects of this nucleotide variation in abdominal fat and fat-tail weight were not significant. Furthermore, Siadkowska et al. (2006) reported correlations between polymorphism in the $5^{\prime}$ non-coding region of the IGF-I gene and lean and fat weight of valuable cuts and a percentage of fat of valuable cuts in Polish HolsteinFriesian cattle. Moreover, concerning the IGF2 gene polymorphism, CT heterozygous Polish Holstein-Friesian bulls had more fat in valuable cuts in the 15th month of life (Zwierzchowski et al., 2010). Also in cattle, Curi et al. (2005) observed a significant association of IGF-I/SnaBI polymorphism in the regulatory region of the $I G F-I$ gene with subcutaneous back fat assessed by ultrasonography. In pigs, Wang et al. (2006) investigated effects of polymorphism of the $I G F-I$ receptor gene $(I G F-I R)$ on back-fat thickness and lean percentage estimated by ultrasonography, and they found less back-fat thickness $(P<0.05)$ and a greater lean percentage $(P<0.01)$ in AA homozygous Yorkshire pigs than BB individuals. To summarise, the results of the abovementioned research showed that polymorphisms in the $I G F-I$ gene, as well as $I G F 2$ and $I G F-I R$, were associated with several fat traits of sheep, cattle and pig carcasses. Indeed, the $I G F-I$ gene was shown to be involved in fat cell development in transgenic mice (Rajkumar et al., 1999). Rajkumar et al. (1999) observed enhanced expression of this gene during differentiation of precursor cells into mature fat cells. Furthermore, Anderson et al. (1988) found that circulating IGF-I protein was negatively correlated with carcass fat percentage, fat accretion rate and fat thickness in Simmental crossbred bulls. Additionally, Davis and Simmen (1997) found associations between lower plasma IGF-I protein concentrations and higher marbling scores as well as dorsal fat thickness in Angus bulls. Concluding, the IGF-I gene should be considered as a potential candidate gene of fat-related carcass traits in sheep.

As mentioned before, among several carcass and carcass cut weights, IGF-I genotype was only associated with fore shank weight in Coloured Polish Merino lambs. Contrary to our results, other authors showed an effect of this gene's polymorphism on carcass weights. For example, Behzadi et al. (2015) reported a tendency of the IGF-I gene polymorphism to be associated with carcass weight $(P=0.07)$. Moreover, Sun et al. (2014) found that an expression of the $I G F-I$ gene was positively correlated with carcass weight in $\mathrm{Hu}$ sheep. Siadkowska et al. (2006) observed a correlation between polymorphism in the $5^{\prime}$ non-coding region of the IGF-I gene and cold carcass weight in Polish HolsteinFriesian cattle. Curi et al. (2005) found significant association of $I G F-I / S n a \mathrm{BI}$ polymorphism in the regulatory region of the IGF-I gene with hot carcass weight, but the effect of this SNP on carcass yield was insignificant in beef cattle. Zwierzchowski et al. (2010) reported effects of the IGF2 gene polymorphism on cold carcass weight and percentage meat content in valuable cuts at the age of 11 months in Polish Holstein-Friesian cattle. It should be pointed out that there is a dearth of information about the association of the IGF-I gene polymorphism with carcass traits in sheep. To our knowledge, until now only Behzadi et al. (2015) had investigated effects of SNP in this gene on carcass traits in Iranian sheep. In the current study we reported results of association analyses in Polish sheep breeds involving new carcass traits, which have not been investigated before. These results suggest that the IGF-I gene should be considered as a potential candidate gene of carcass traits in sheep, and similar studies involving other sheep breeds in different countries should be continued.

In this study, association analysis between the $I G F-I$ gene polymorphism and meat quality traits was undertaken. A significant effect of IGF-I SNP on natural drip loss in Coloured Polish Merino sheep was found. Meat from AA male lambs had lower natural drip loss than meat from heterozygous individuals. Moreover, an association of this nucleotide variation in the $I G F-I$ gene with subjective meat colour was observed. In this case, meat from AA homozygous ram lambs was slightly darker than meat from heterozygotes. Little is known about associations of the IGF-I gene polymorphism with meat quality traits in sheep. To our knowledge, this study is the first that presents the effect of IGF-I genotypes on several new meat quality traits in sheep. Other authors have shown association analyses of the IGF-I gene polymorphism with various meat quality traits in sheep, but with different traits than investigated in this study. For example, Behzadi et al. (2015) found significant effects of nucleotide variation in the first exon of the $I G F-I$ gene with the level of triglycerides and cholesterol in blood. Su et al. (2014) analysed relationships of the IGF-I gene expression in $L D$ muscle with meat quality traits in Hu sheep. They observed that the expression of this gene was positively and significantly $(\mathrm{P}<0.01)$ correlated with muscle fibre diameter and muscle fibre shear stress, and negatively and significantly $(P<0.01)$ correlated with muscle fibre density. Furthermore, Davis and Simmen (1997) showed that lower plasma IGF-I protein concentrations were associated with higher marbling scores in Angus cattle. Wang et al. (2009) observed an effect of the $I G F B P-3$ gene polymorphism on meat colour in pigs. More- 
over, Wang et al. (2010) found an association between the $I G F B P-5$ gene and $\mathrm{pH}$ of various meat cuts in pigs. SNPs in the $I G F-I$ gene may have a direct or indirect effect on meat quality traits in sheep, cattle and pigs. There is also a possibility that SNPs detected in the IGF-I gene are not causative mutations for the investigated effects on meat quality traits, but are markers in linkage with the causative mutations in the other genes. As the results of this study constitute the first information gathered on the IGF-I gene polymorphism association with several meat quality parameters in sheep, further investigation should be carried out to evaluate potential breed-specific effects of SNPs in this gene on lamb quality.

\section{Conclusion}

In the present study, information about the IGF-I gene polymorphism and its effect on a wide range of growth, body size, carcass and meat quality traits in Coloured Polish Merino sheep were reported. Associations between IGF-I genotype and fore shank weight $(P=0.006)$, kidney fat class $(P=0.002)$, EUROP fat class $(P=0.005)$, external fatness of carcass class $(P=0.038)$, natural drip loss $(P=0.049)$ and subjective assessment of meat colour $(P=0.043)$ were found. Therefore, the IGF-I gene polymorphism could be used as a marker for an improvement of these traits in Coloured Polish Merino sheep. Moreover, in the case of several investigated traits, the present study provided the first information about the effect of this marker in sheep. Concluding, the results suggest that the $I G F-I$ gene could be considered as a candidate gene of certain carcass and meat quality traits in sheep; however, further investigations are recommended in other sheep breeds in the world in order to evaluate potential breed- and/or flock-specific effects of this gene's polymorphism on sheep production traits. Furthermore, the $I G F-I$ gene is well known for its role in many processes in an organism, which is a result of its pleiotropic function; therefore, before using IGF-I polymorphism in a production system, association analyses regarding other traits, which were not investigated in this study, i.e. reproductive and milk production attributes, should be carried out to confirm that selection will not have negative consequences for the breed.

Data availability. The original data of the paper will be available upon request to the corresponding author.

Competing interests. The authors declare that they have no conflict of interest.

Acknowledgements. This project was founded by National Science Centre, Poland, project no. NN311521440. Part of this work was supported by the project "Realization of the second stage of the Regional Innovation Centre", which was co-financed by the European Regional Development Fund under the Regional Operational Programme for Kujawsko-Pomorskie Voivodeship for the years 2007-2013.

Edited by: Steffen Maak

Reviewed by: Roman Niżnikowski and two anonymous referees

\section{References}

Akers, R. M.: Major advances associated with hormone and growth factor regulation of mammary growth and lactation in dairy cows, J. Dairy Sci., 89, 1222-1234, 2006.

Anderson, P. T., Bergen, W. G., Merkel, R. A., Enright, W. J., Zinn, S. A., Refsal, K. R., and Hawkins, D. R.: The relationship between composition of gain and circulating hormones in growing beef bulls fed three dietary crude protein levels, J. Anim. Sci., 66, 3059-3067, 1988.

Baker, J., Liu, J. P., Robertson, E. J., and Efstratiadis, A.: Role of insulin-like growth factors in embryonic and postnatal growth, Cell, 75, 73-82, 1993.

Baryłko-Pikielna, N.: Zarys analizy sensorycznej żywności, Wydawnictwo Naukowo-Techniczne, Warszawa, 1975.

Baxter, R. C.: The somatomedins: insulin-like growth factors, Adv. Clin. Chem., 25, 49-115, 1986.

Behzadi, S., Miraei-Ashtiani, S. R., Sadeghi, M., Zamani, P., and Abdoli, R.: Association of IGF-I gene polymorphisms with carcass traits in Iranian Mehraban sheep using SSCP analysis, Iran. J. Appl. Anim. Sci., 5, 121-126, 2015.

Breier, B. H., Gluckman, P. D., and Mass, J. J.: Plasma concentrations of insulin-like growth factor I and insulin in the infant calf: ontogeny and influence of alter nutrition, J. Endocrinol., 119, 4350, 1988.

Burgos, S. A. and Cant, J. P.: IGF-I stimulates protein synthesis by enhanced signaling through mTORC1 in bovine mammary epithelial cells, Domest. Anim. Endocrinol., 38, 211-221, 2010.

Chelongar, R., Hajihosseinlo, A., and Ajdary, M.: The effect of Igf-1 and Pit-1 genes polymorphisms on fat-tail measurements (fat-tail dimensions) in Makooei sheep, Adv. Environ. Biol., 8, 862-867, 2014.

Clemmons, D. R., Dehoff, M., McCusker, R., Elgin, R., and Busby, W.: The role of insulin-like growth factor I in the regulation of growth, J. Anim. Sci., 65, 168-179, 1987.

Curi, R. A., Oliveira, H. N., Silveira, A. C., and Lopes, C. R.: Association between IGF-I, IGF-IR and GHRH gene polymorphisms and growth and carcass traits in beef cattle, Livest. Prod. Sci., 94, 159-167, 2005.

Davis, M. E. and Simmen, R. C. M.: Genetic parameter estimates for serum insulin-like growth factor concentration and performance traits in Angus beef cattle, J. Anim. Sci., 75, 317-324, 1997.

De la Rosa Reyna, X. F., Montoya, H. M., Castrellón, V. V., Rincón, A. M. S., Bracamonte, M. P., and Vera, W. A.: Polymorphisms in the IGF1 gene and their effect on growth traits in Mexican beef cattle, Genet. Mol. Res., 9, 875-883, 2010.

Duclos, M. J., Beccavin, C., and Simon, J.: Genetic models for study of Insulin-like growth factors (IGF) and muscle development in birds compared to mammals, Domest. Anim. Endocrinol., 17, 231-243, 1999. 
Excoffier, L. and Lischer, H. E. L.: Arlequin suite ver 3.5: a new series of programs to perform population genetics analyses under Linux and Windows, Mol. Ecol. Resour., 10, 564-567, 2010.

Froesch, E. R., Schmid, C., Schwander, J., and Zapf, J.: Actions of insulin-like growth factors, Annu. Rev. Physiol., 47, 443-467, 1985.

Gao, X., Shi, M., Xu, X., Li, J., Ren, H., and Xu, S.: Sequence variations in the bovine IGF-I and IGFBP3 genes and their association with growth and development traits in Chinese Beef Cattle, Agric. Sci. China, 8, 717-722, 2009.

Ge, W., Davis, M. E., and Hines, H. C.: Two SSCP alleles detected in the $5^{\prime}$-flanking region of bovine IGF-I gene, J. Anim. Genet., 28, 155-156, 1997.

Ge, W., Davis, M. E., Hines, H. C., Irvin, K. M., and Simmen, R. C.: Association of a genetic marker with blood serum insulin-like growth factor-I concentration and growth traits in Angus cattle, J. Anim. Sci., 79, 1757-1762, 2001.

Gholibeikifard, A., Aminafshar, M., and Hosseinpour Mashhadi, M.: Polymorphism of IGF-I and ADRB3 Genes and Their Association with Growth Traits in the Iranian Baluchi Sheep, J. Agr. Sci. Tech., 15, 1153-1162, 2013.

Grau, R. and Hamm, R.: Eine einfache Mathode zur Bestimmung der Wasserbindung in Fleisch, Fleischwirtschaft, 4, 295-297, 1952.

Hajihosseinlo, A., Hashemi, A., Razavi-Sheshdeh, S. A., and Pirany, N.: Association of the polymorphism in the $5^{\prime}$ flanking region of the ovine IGF-I gene with growth and development traits in Makui sheepof Iran, Eur. J. Zoolog. Res., 2, 19-24, 2013.

He, J. N., Zhang, B. Y., Chu, M. X., Wang, P. Q., Feng, T., Cao, G. L., Di, R., Fang, L., Huang, D. W., Tang, Q. Q., and Li, N.: Polymorphism of insulin-like growth factor 1 gene and its association with litter size in Small Tail Han sheep, Mol. Biol. Rep., 39, 9801-9807, 2012.

ISO 1442: Meat and meat products, Determination of water content, 2000.

ISO 1444: Meat and meat products, Determination of free fat content, 2000.

ISO 2917: Meat and meat products, Measurement of $\mathrm{pH}$ - reference method, 2001.

Jarrige, R.: Alimentation des bovins, ovins et caprins, FRA, INRA Editions, Paris, 1988.

Jones, J. I. and Clemmons, D. R.: Insulin-like growth factors and their binding proteins: biological actions, Endocr. Rev., 16, 334, 1995.

Kawęcka, A.: Coloured Polish Mountain Sheep - implementation of the genetic resources conservation programme, breed characteristics and assessment of product quality, Roczniki Naukowe Zootechniki, Monografie i Rozprawy, National Research Institute of Animal Production, Kraków, Poland, 2013.

Kazemi, S. M., Amirinia, C., Emrani, H., and Gharahveysi, S.: Study and Identification of Insulin-Like Growth Factor-I Gene Polymorphisms in Zel Sheep Population, Am. J. Anim. Vet. Sci., 6, 176-179, 2011.

Krupiński, J., Borys, B., Kmieć, W., Knapik, J., Korman, K., Osikowski, M., Pompa-Roborzyński, M., and Rzepecki, R.: Ocena użytkowości mięsnej jagniąt na tle wymogów oraz metod stosowanych w krajach Unii Europejskiej, National Research Institute of Animal Production, Kraków, Poland, 2009.
Lackey, B. R., Gray, S. L., and Henricks, D. M.: The insulin-like growth factor (IGF) system and gonadotropin regulation: actions and interactions, Cytokine Growth F. R., 10, 201-217, 1999.

Li, C., Basarab, J., Snelling, W. M., Benkel, B., Murdoch, B., Hansen, C., and Moore, S.: Assessment of positional candidate genes myf5 and IGF1 for growth on bovine chromosome 5 in commercial lines of Bos taurus, Anim. Sci., 82, 1-7, 2004.

Lynch, C. O., Mullen, M. P., Waters, S. M., Howard, D. J., O’Boyle, P., Berry, D. P., Kenny, D. A., Buckley, F., Horan, B., and Diskin, M. G.: Single nucleotide polymorphisms in the growth hormone and insulin-like growth factor 1 genes are associated with production and fertility traits in dairy cows, BSAS Advances in Animal Biosciences (BSAS \& IGAPA 12th-14th April 2010, Whitla Hall, Queen's University, Belfast, Northern Ireland), Cambridge University Press, Belfast, 314 pp., 2010.

Moradian, C., Esmailnia, G., and Hajihosseinlo, A.: Polymorphism of IGF-1 gene in Makoei Sheep using PCR-SSCP European, J. Exp. Biol., 3, 490-494, 2013.

Mullen, M. P., Berry, D. P., Howard, D. J., Diskin, M. G., Lynch, C. O., Giblin, L., Kenny, D. A., Magee, D. A., Meade, K. G., and Waters, S. M.: Single nucleotide polymorphisms in the insulin-like growth factor 1 (IGF-1) gene are associated with performance in Holstein-Friesian dairy cattle, Front. Genet., 2, 3, https://doi.org/10.3389/fgene.2011.00003, 2011.

Nawara, W., Osikowski, M., Kluz, I., and Modelska, M.: Wycena tryków na podstawie badania wartości potomstwa w Stacjach Oceny Tryków Instytutu Zootechniki za rok 1962, Wydawnictwo własne Instytutu Zootechniki w Polsce Nr 166, Państwowe Wydawnictwo Rolnicze i Leśne, Warszawa, RI, 1963.

Nazari, F., Noshary, A., and Hemati, B.: Association between insulin-like growth factor I polymorphism and early growth traits in Iranian Zandi Sheep, Found Polymerase Chain Reaction Restriction Fragment Length Polymorphism (PCR-RFLP), Iran. J. Appl. Anim. Sci., 6, 665-669, 2016.

Negahdary, M., Hajihosseinlo, A., and Ajdary, M.: PCR-SSCP variation of IGF1 and PIT1 genes and their association with estimated breeding values of growth traits in Makooei Sheep, Genet. Res. Int., 6, 272346, https://doi.org/10.1155/2013/272346, 2013.

Niżnikowski, R., Czub, G., Świątek, M., Ślęzak, M., and Głowacz, K.: Polymorphism of insulin-like growth factor IGF-1 gene in selected Polish sheep breeds, Ann. Warsaw Univ. of Life Sci. SGGW, Anim. Sci., 54, 129-132, 2015.

Oksbjerg, N., Gondret, F., and Vestergaard, M.: Basic principles of muscle development and growth in meat producing mammals as affected by the insulin-likegrowth factor (IGF) system, Domest. Anim. Endocrinol., 27, 219-240, 2004.

PN-75/A-04018: Food-agricultural products, Determination of nitrogen and to the protein conversion, 2000.

Pohja, N. S. and Ninivaara, F.P .: Die Bestimmung der Wasserbindung des Fleisches mittels der Konstandrückmethods, Fleischwirschaft, 9, 193-195, 1957.

Proskura, W. S. and Szewczuk, M.: The polymorphism in the IGF1R gene is associated with body weight and average daily weight gain in Pomeranian Coarsewool ewes, Pak. Vet. J., 34, 514-517, 2014.

Rajkumar, K., Modric, T., and Murphy, L. J.: Impaired adipogenesis in insulin-like growth factor binding protein-I transgenic mice, J. Endocrinol., 162, 457-465, 1999. 
SAS: SAS 9.2, Statistical Analyses System User's Guide, SAS Institute Inc., Cary, NC, USA, 2008.

Scatà, M. C., Catillo, G., Annicchiarico, G., Matteis, G. D., Napolitano, F., Signorelli, F., and Moioli, B.: Investigation on lactation persistency and IGF-I gene polymorphisms in dairy sheep, Small Rumin. Res., 89, 7-11, 2010.

Schams, D., Berisha, B., Einspanier, R., and Amelgruber, W. M.: Possible role of growth hormone, IGFs, and IGF-binding proteins in the regulation of ovarian function in large farm animals, Domest. Anim. Endocrinol., 17, 279-285, 1999.

Siadkowska, E., Zwierzchowski, L., Oprządek, J., Strzałkowska, N., Bagnicka, E., and Krzyżewski, J.: Effect of polymorphism in IGF-1 gene on production traits in Polish Holstein-Friesian cattle, Anim. Sci. Pap. Rep., 24, 225-237, 2006.

Su, R., Sun, W., Li, D., Wang, Q. Z., Lv, X. Y., Musa, H. H., Chen, L., Zhang, Y. F., and Wu, W. Z.: Association between DLK1 and IGF-I gene expression and meat quality in sheep, Genet. Mol. Res., 13, 10308-10319, 2014.

Sun, W., Su, R., Li, D., Musa, H. H., Kong, Y., Ding, J. T., Ma, Y. H., Chen, L., Zhang, Y. F., and Wu, W. Z.: Developmental changes in IGF-I and MyoG gene expression and their association with meat traits in sheep, Genet. Mol. Res., 13, 2772-2783, 2014.

Szewczuk, M., Bajurna, M., Zych, S., and Kruszyński, W.: Association of insulin-like growth factor I gene polymorphisms (IGF1/TasI and IGF1/SnaBI) with the growth and subsequent milk yield of Polish Holstein-Friesian heifers, Czech J. Anim. Sci., 58, 404-411, 2013.

Tahmoorespur, M., Valeh, M. V., Nassiry, M. R., Moussavi, A. H., and Ansary, M.: Association of the polymorphism in the $5^{\prime}$ flanking region of the ovine IGF-I gene with growth traits in the Baluchi sheep, S. Afr. J. Anim. Sci., 39, 97-101, 2009.
Wang, W., Meng, Q., Hu, X., and Li, N.: Genetic variation and association of insulin-like growth factor binding protein-3 with performance in Swine, Biochem. Genet., 47, 315-321, 2009.

Wang, W., Ouyang, K., Shangguan, X., and Xu, M.: Association of porcine IGF binding protein-5 gene with meat quality, Biochem. Genet., 48, 257-265, 2010.

Wang, W., Ouyang, K., Su, X., Xu, M., and Shangguan, X.: Polymorphism of insulin-like growth factor 1 receptor gene in 12 pig breeds and its relationship with pig performance traits, AsianAust. J. Anim. Sci., 19, 1541-1545, 2006.

Yakar, S., Rosen, C. J., Beamer, W. G., Ackert-Bicknell, C. L., Wu, Y., Liu, J. L., Ooi, G. T., Setser, J., Frystyk, J., Boisclair, Y. R., and Le Roith, D.: Circulating levels of IGF-I directly regulate bone growth and density, J. Clin. Invest., 110, 771-781, 2002.

Yilmaz, A., Davis, M. E., Hines, H. C., and Chung, H.: Detection of two nucleotide substitutions and putative promoters in the $5^{\prime}$ flanking region of the ovine IGF-I gene, J. Appl. Genet., 46, 307-309, 2005.

Zapf, J. and Froesch, E. R.: Insulin-like growth factor-I actions on somatic growth, in: Handbook o Physiology, edited by: Kostyo, J. L., Oxford University Press, New York, 1999.

Zhang, C., Zhang, W., Luo, H., Yue, W., Gao, M., and Jia, Z.: A new single nucleotide polymorphism in the IGF-I gene and its association with growth traits in the Nanjiang Huang Goat, Asian-Aust. J. Anim. Sci., 21, 1073-1079, 2008.

Zwierzchowski, L., Siadkowska, E., Oprządek, J., Flisikowski, K., and Dymnicki, E.: An association of $\mathrm{C} / \mathrm{T}$ polymorphism in exon 2 of the bovine insulin-like growth factor 2 gene with meat production traits in Polish Holstein-Friesian cattle, Czech. J. Anim. Sci., 55, 227-233, 2010. 